\title{
INFLUENCE OF PHOTOPERIOD ON THE UPTAKE OF NITROGEN AND PHOSPHORUS IN THE WATER BY Eichhornia crassipes AND Salvinia auriculata
}

\author{
PETRUCIO, M. M. and ESTEVES, F. A. \\ Universidade Federal do Rio de Janeiro, Instituto de Biologia, Departamento de Ecologia, \\ Laboratório de Limnologia, Cidade Universitária, CEP 21941-590, Rio de Janeiro, RJ, Brazil \\ Correspondence to: M. M. Petrucio, Universidade Federal do Rio de Janeiro, Instituto de Biologia, Departamento \\ de Ecologia, Laboratório de Limnologia, Cidade Universitária, CEP 21941-590, Rio de Janeiro, RJ, Brazil, \\ e-mail: petrucio@mono.icb.ufmg.br \\ Received February 4, 1999 - Accepted December 13, 1999 - Distributed August 31, 2000
}

\begin{abstract}
The main goal of this research was to quantify the concentrations of total and ammonium $\mathrm{N}$, nitrate, total and soluble $\mathrm{P}$ in the water in the presence of Eichhornia crassipes and Salvinia auriculata, which were submitted to two different photoperiods in a 24 hours incubation period in the laboratory. The macrophytes were incubated in plastic vials of approximately 1.5 litters, with a previously prepared solution with $\mathrm{NH}_{4} \mathrm{NO}_{3}, \mathrm{NH}_{4} \mathrm{Cl}$, and $\mathrm{KH}_{2} \mathrm{PO}_{4}$. Eichhornia crassipes showed the highest average rate of reduction of all the nutrients analysed in relation to Salvinia auriculata. The largest photoperiod reflected in a higher average rate of reduction of nutrients, in both plants. Therefore, we may expect that in some periods of the year (e.g. summer), the aquatic macrophytes would show higher growth rates and higher rates of nitrogen and phosphorus absorption. These results are important for the implementation and management of wastewater treatment systems in tropical areas using aquatic macrophytes.
\end{abstract}

Key words: Eichhornia crassipes, aquatic macrophytes, nitrogen, phosphorus, Salvinia auriculata.

\section{RESUMO}

\section{Influência do fotoperíodo na absorção de nitrogênio e fósforo na água por Eichhornia crassipes e Salvinia auriculata}

Esta pesquisa teve por fundamental objetivo quantificar as concentrações de nitrogênio total, amoniacal, nitrato, fósforo total e solúvel reativo na água na presença de Eichhornia crassipes e Salvinia auriculata, que foram submetidas a dois fotoperíodos diferentes. As macrófitas foram incubadas em laboratório, durante 24 horas, em frascos de plástico de aproximadamente 1,5 litros, com um solução que foi preparada previamente com $\mathrm{NH}_{4} \mathrm{NO}_{3}, \mathrm{NH}_{4} \mathrm{Cl}$ e $\mathrm{KH}_{2} \mathrm{PO}_{4}$. Eichhornia crassipes apresentou os maiores porcentuais médios de reduções de todos os nutrientes analisados em relação a Salvinia auriculata. O aumento do fotoperíodo refletiu em um aumento dos porcentuais médios de redução de nutrientes, para ambas as plantas. Com isso, é esperado que em alguns períodos do ano (por exemplo no verão) as macrófitas aquáticas possam apresentar maiores taxas de crescimento e de absorção de nitrogênio e fósforo. Esses resultados são importantes para a implementação e manejo de sistemas de tratamento de efluentes, em áreas tropicais, que usam macrófitas aquáticas.

Palavras-chave: Eichhornia crassipes, macrófitas aquáticas, nitrogênio, fósforo, Salvinia auriculata. 


\section{INTRODUCTION}

Many studies (Reddy \& Smith, 1987; Kadlec \& Knight, 1996) have emphasised the role of the aquatic macrophytes play in treating water bodies subjected to the dumping of domestic and industrial effluents.

These plant species can accumulate nutrients, especially nitrogen and phosphorus, which are the principal compounds responsible for eutrophication in lacustrine environments.

Eichhornia crassipes may be considered as the most important and commonly used species of aquatic macrophytes used to treat domestic effluents (Brix, 1993). Gopal (1987) cited many studies of this species and reports different rates of nutrient uptake. Thus, showing the high potential of this species to remove many compounds. The species of the genus Salvinia exhibit a lower efficiency in systems of sewage treatment, when compared to other floating aquatic macrophytes (Reddy \& Debusk, 1985; Tripathi et al., 1991). According to ROOM (1986), these plants can offer efficient pollution removal only when carefully managed.

Processes that are not fully understood determine the removal of nitrogen and phosphorus by aquatic macrophytes in wetlands. However some of these processes can directly influence the dynamics of aquatic macrophytes (Reddy \& D'Angelo, 1997). According to some studies, the growth rate of floating aquatic macrophytes is directly related to the intensity and amount of light. Therefore, light intensity and quantity along with temperature are the most important factors influencing the absorption rates for nutrients and the productivity of these plants (Gopal, 1987; Urbanc-Bercic \& Gaberscik, 1989; Sharma \& Edem, 1991).

The main goal of this study is to quantify the influence of two photoperiods on the removal capacity of nitrogen and phosphorus compounds in the water by the activity of E. crassipes and $S$. auriculata. From laboratory experiments, we may infer whether periods of the year with a greater light incidence (e. g. summer) will cause greater nutrient absorption performed by the aquatic macrophytes. These data are relevant for the development and implementation of successful sewage treatment systems in tropical areas using aquatic macrophytes.

\section{METHODS}

The floating aquatic macrophytes Eichhornia crassipes and Salvinia auriculata were manually collected in the mouth of the largest sewage channel in a tropical coastal lagoon (Imboassica Lagoon) (Petrucio \& Esteves, in preparation). This lagoon is located in the municipality of Macaé (22 $50^{\circ} \mathrm{S}$ and $44^{\circ} 42^{\prime} \mathrm{W}$ ) approximately $190 \mathrm{Km}$ to the north of the city of Rio de Janeiro, RJ (Furtado et al., 1997). The plants were washed in the laboratory under flowing water and incubated for 24 hours in a germination chamber (Fanem, Mod. 347 $\mathrm{CDG}$ ), under controlled temperature and light intensity conditions $\left(25^{\circ} \mathrm{C}\right.$ and $175 \mu \mathrm{E} / \mathrm{m}^{2} / \mathrm{seg}$, respectively).

The aquatic macrophytes and the controls (flasks without plants) were incubated in plastic flasks containing a volume of $700 \mathrm{ml}$ of a previously prepared solution of water from Imboassica lagoon with the addition of a compound of ammonium nitrate $\left(\mathrm{NH}_{4} \mathrm{NO}_{3}\right)$, ammonium chloride $\left(\mathrm{NH}_{4} \mathrm{Cl}\right)$ and dibasic potassium phosphate $\left(\mathrm{KH}_{2} \mathrm{PO}_{4}\right)$. The final solution contained concentrations of approximately $0.5 \mathrm{mg} / \mathrm{l}$ of $\mathrm{NO}_{3}, 1.0 \mathrm{mg} / \mathrm{L}$ of $\mathrm{NH}_{4}$, and $0.5 \mathrm{mg} / \mathrm{L}$ of $\mathrm{PO}_{4}$.

A young individual of Eichhornia crassipes, with an average of three leaves of $4 \times 7 \mathrm{~cm}$, was placed in each flask. For Salvinia auriculata, each flask received an individual with approximately 6 fronds with a diameter of $1.0 \mathrm{~cm}$. Before and after 24 hours of incubation, the temperature, salinity, electric conductivity of the water (digital thermo-salinometer-conductivimeter, LabComp SCT) and the concentrations of nitrogen and phosphorus were quantified. At the end of the experiment the plants were removed from the flasks and placed in a drying oven $\left(70^{\circ} \mathrm{C}\right)$ in order to obtain the dry weight of the plant material.

The dissolved fraction of the nutrients was obtained by filtration with GF 52/C (Schlücher \& Schüll) filters, which were later used for the determination of chlorophyll- $a$, according to Nusch \& Palme (1975). The concentration of total nitrogen $(\mu \mathrm{g} / \mathrm{L})$ was obtained according to Mackereth et al. (1978) and the ammonium nitrogen $(\mu \mathrm{g} / \mathrm{L})$ according to Grasshoff (1976). The concentration of nitrate $(\mu \mathrm{g} / \mathrm{L})$ was obtained after reduction to nitrite in amalgamated cadmium columns, according to Mackereth et al. (1978). Total phosphorus 
$(\mu \mathrm{g} / \mathrm{L})$ and reactive soluble phosphorus $(\mu \mathrm{g} / \mathrm{L})$ were determined according to Golterman et al. (1978), and dissolved oxygen according to Winkler, with the modifications proposed by Golterman et al. (1978).

Variance analysis (ANOVA) was applied to each nutrient that was analysed in order to verify whether they were significantly different among the samples (E. crassipes and S. auriculata) and among the treatments (photoperiod). Furthermore, the values of chlorophyll- $a$ were analysed against the nutrient concentrations by means of the Pearson linear correlation in order to see if there significant correlations exist between these parameters.

\section{RESULTS}

The initial concentrations of dissolved oxygen in the water of the flasks containing E. crassipes were higher than those in the flasks with $S$. auriculata (Table 1). However all of the flasks had a high recorded concentrations (> 90\%Sat). The concentrations of chlorophyll- $a$ did not vary thought the experiment in the flasks with $E$. crassipes, only the controls exhibited a decrease. In the treatments with $S$. auriculata and in the respective controls, a increase was observed in the chlorophyll- $a$ concentrations in all of the flasks at the end of the experiment.

The concentrations of nutrients in the water showed very little fluctuation (Table 1). The nitrate values in all of the controls and in S. auriculata exhibited increases related to the initial concentration (To). For the other nutrients, a decrease was observed in the concentrations after 24 hours of incubation in all of the flasks. The high percentage of decrease of total phosphorus (79.1\%) and reactive soluble phosphorus $(84.4 \%)$ in $E$. crassipes must be noted, when incubated with 12 hours of photoperiod. The samples with $S$. auriculata had lower percentages of decrease. Chlorophyll- $a$ did not exhibit any significant correlation with the nutrients that were analysed in all of the flasks with plants over in both photoperiods (Table 2).

The reduction in the concentrations of nutrients in the water with E. crassipes, were significantly different from those obtained with $S$. auriculata (Table 3 ). It may be said that E. crassipes exhibited a significantly greater percentage of reduction in the analysed nutrients in both photoperiods. Regarding the comparison between the treatments (F10 and 12) the differences are also significant for both species. Therefore the flasks were exposed for 12 hours to light had a significantly greater percentage of reduction when compared to those which had only 10 hours (except for nitrate concentrations) in all of the flasks. The controls exhibited a reduction in the concentrations of nutrients significantly different from those obtained in the flasks with plants, except for the concentration of nitrate, which, was not significantly different from those obtained with $S$. auriculata.

\section{DISCUSSION}

According to Gopal (1987) the optimum temperature for Eichhornia crassipes is around $25^{\circ} \mathrm{C}$. Higher rates of absorption of $\mathrm{N}$ and $\mathrm{P}$ were observed during the summer, for this same species (Reddy \& Tucker, 1983; Urbanc-Bercic \& Gaberscik, 1989). Whiteman \& Room (1991), in laboratory experiments with controlled temperatures, have shown that Salvinia molesta, when exposed to temperatures below -3 our above $43^{\circ} \mathrm{C}$, died after an interval of 2 to 3 hours. Cary \& Weerts (1983a, b, 1984) also worked with $S$. molesta, and revealed that the best rates of production and absorption of nutrients, especially nitrogen and phosphorus, were in the range of water temperature between 24 and $28^{\circ} \mathrm{C}$. According to Room \& Kerr (1983) the temperature is directly related to the growth rates of this species. From the reports cited, it may be concluded that the temperature has a direct influence on nutrient absorption capacity and that in this experiment the plants were incubated in the ideal temperature $\left(25^{\circ} \mathrm{C}\right)$ for their optimum production.

The concentration of chlorophyll- $a$ in the water may be used as an estimate of the phytoplanktonic activity (Wetzel, 1981). The low values of chlorophyll- $a(<9 \mu \mathrm{g} / \mathrm{L})$ associated with the small fluctuations of dissolved oxygen observed in the flasks may indicate a smaller influence of the phytoplanktonic community in the percentages of nutrient reduction.

This fact, as well as the results obtained in the controls (Table 1), demonstrates the role aquatic macrophytes play in the absorption of nitrogen and phosphorus from the water column. 
TABLE 1

Concentrations of nitrogen and phosphorus in the water of the flasks with $E$. crassipes (E), S. auriculata (S) and controls $(C)$, incubated under the influence of two different photoperiods (Group 10 and 12). Percent red, represents the average percentage of reduction in the concentrations of nutrients.

\begin{tabular}{|c|c|c|c|c|c|c|c|c|}
\hline Sample & & $\begin{array}{c}\text { TN } \\
(\mu \mathrm{g} / \mathrm{L})\end{array}$ & $\begin{array}{l}N^{3}-N \\
(\mu \mathrm{g} / \mathrm{L})\end{array}$ & $\begin{array}{l}N^{4}-\mathbf{N} \\
(\mu \mathrm{g} / \mathrm{L})\end{array}$ & $\begin{array}{c}\text { TP } \\
(\mu \mathrm{g} / \mathrm{L})\end{array}$ & $\begin{array}{l}\mathrm{PO}^{4} \mathrm{P}- \\
(\mu \mathrm{g} / \mathrm{L})\end{array}$ & $\begin{array}{c}\text { D,O } \\
(\% \text { Sat })\end{array}$ & $\begin{array}{l}\text { Chlor, } \\
(\mu \mathrm{g} / \mathrm{L})\end{array}$ \\
\hline \multicolumn{9}{|l|}{ F10 } \\
\hline To & & 1764.0 & 489.8 & 968.6 & 375.5 & 355.5 & 130.8 & 2.8 \\
\hline \multirow[t]{3}{*}{$\mathrm{C}$} & Average & 1713.6 & 496.8 & 925.3 & 367.1 & 333.3 & 119.5 & 0.8 \\
\hline & SD & 25.2 & 2.5 & 10.6 & 1.7 & 5.1 & 1.6 & 1.1 \\
\hline & Average & 1441.4 & 280.4 & 582.1 & 113.1 & 90.6 & 118.1 & 2.1 \\
\hline \multirow[t]{2}{*}{$\mathrm{E}$} & SD & 83.0 & 45.0 & 84.2 & 26.5 & 18.3 & 3.3 & 2.1 \\
\hline & $\%$ red & 18.3 & 42.8 & 39.9 & 69.9 & 74.5 & & \\
\hline To & & 1663.2 & 521.3 & 759.7 & 368.8 & 308.8 & 89.7 & 1.1 \\
\hline \multirow[t]{3}{*}{$\mathrm{C}$} & Average & 1629.6 & 539.3 & 687.3 & 358.5 & 281.0 & 92.0 & 6.4 \\
\hline & SD & 38.5 & 5.9 & 9.8 & 2.2 & 3.8 & 0.8 & 2.2 \\
\hline & Average & 1517.0 & 548.4 & 610.4 & 327.7 & 253.3 & 90.3 & 8.2 \\
\hline \multirow[t]{2}{*}{$\mathrm{S}$} & SD & 39.0 & 4.7 & 26.3 & 9.4 & 13.2 & 1.4 & 0.9 \\
\hline & $\%$ red & 8.8 & - & 19.7 & 11.2 & 18.0 & & \\
\hline \multicolumn{9}{|l|}{ F12 } \\
\hline To & & 1764.0 & 489.8 & 968.6 & 375.5 & 355.5 & 130.8 & 2.8 \\
\hline \multirow[t]{3}{*}{$\mathrm{C}$} & Average & 1688.4 & 499.2 & 916.4 & 369.8 & 339.9 & 119.5 & -0.5 \\
\hline & SD & 25.2 & 0.6 & 23.7 & 2.5 & 1.9 & 2.2 & 1.2 \\
\hline & Average & 1310.4 & 305.6 & 532.3 & 78.3 & 55.6 & 119.2 & 2.1 \\
\hline \multirow[t]{2}{*}{$\mathrm{E}$} & SD & 98.7 & 45.6 & 84.9 & 21.5 & 19.2 & 3.4 & 0.8 \\
\hline & $\%$ red & 25.7 & 37.6 & 45.0 & 79.1 & 84.4 & & \\
\hline To & & 1663.2 & 521.3 & 759.7 & 368.8 & 308.8 & 89.7 & 1.1 \\
\hline \multirow[t]{3}{*}{$\mathrm{C}$} & Average & 1629.6 & 548.3 & 723.2 & 359.8 & 284.4 & 91.4 & 8.3 \\
\hline & SD & 58.2 & 6.3 & 16.6 & 2.5 & 6.7 & 0.3 & 2.3 \\
\hline & Average & 1509.5 & 551.8 & 573.2 & 312.3 & 242.3 & 92.0 & 9.0 \\
\hline \multirow[t]{2}{*}{$\mathrm{S}$} & SD & 43.6 & 8.8 & 36.8 & 13.7 & 16.8 & 1.7 & 2.3 \\
\hline & $\%$ red & 9.2 & - & 24.6 & 15.3 & 21.5 & & \\
\hline
\end{tabular}

$\mathrm{SD}=$ Standard Deviation; To $=$ Initial concentration of the samples.

The percentages of nutrient reduction found in the literature exhibit a great range of fluctuation. For the concentrations of total nitrogen values between $50 \%$ and $96 \%$ of reduction were found, and for phos- phorus between $36 \%$ and $90 \%$, allowing for the environmental conditions to which E. crassipes is exposed (Debusk \& Reddy, 1987; Tripathi et al., 1991; Sharma \& Oshodi, 1991; Zakova et al. 1994). 
TABLE 2

Pearson linear correlation demonstrating the concentrations of chlorophyll-a and those of nitrogen and phosphorus, obtained from the incubated samples with $E$. crassipes and $S$. auriculata exposed to two different photoperiod (F10 and 12). Significant values close to 1.

\begin{tabular}{|l|c|c|c|c|}
\hline & \multicolumn{3}{|c|}{ Chlorophyll- $\boldsymbol{c}$} \\
\hline & \multicolumn{2}{|c|}{ F10 } & 0.45 & 0.12 \\
\hline $\mathrm{TN}$ & $-0,63$ & -0.14 & -0.61 & -0.3 \\
\hline $\mathrm{NO}^{3}-\mathrm{N}$ & -0.28 & -0.35 & -0.17 & 0.63 \\
\hline $\mathrm{NH}^{4}-\mathrm{N}$ & -0.04 & -0.36 & -0.37 & 0.31 \\
\hline $\mathrm{TP}$ & 0 & 0.71 & -0.36 & 0.22 \\
\hline $\mathrm{PO}^{4}-\mathrm{P}$ & -0.06 & -0.12 & E. crassipes & S. auriculata \\
\hline & E. crassipes & S. auriculata & & \\
\hline
\end{tabular}

TABLE 3

Results of the variance analysis (ANOVA) between the samples of $E$. crassipes (E), S. auriculata (S) and controls (C); and between the treatments (Photoperiod of 10 and 12 hours). *Significant values $p<0.05$.

\begin{tabular}{|l|c|c|c|c|c|c|c|c|c|c|}
\hline Factor & \multicolumn{2}{|c|}{ TN } & \multicolumn{2}{c|}{ NH $^{4}-\mathbf{N}$} & \multicolumn{2}{c|}{ NO $^{3}-\mathbf{N}$} & \multicolumn{2}{c|}{ TP } & \multicolumn{2}{c|}{ PO $^{4}-\mathbf{P}^{\mid}$} \\
\hline & $\mathbf{H}$ & $\mathbf{p}$ & $\mathbf{H}$ & $\mathbf{p}$ & $\mathbf{H}$ & $\mathbf{p}$ & $\mathbf{H}$ & $\mathbf{p}$ & $\mathbf{H}$ & $\mathbf{p}$ \\
\hline Samples & & & & & & & & & & \\
\hline E X C & 48.98 & $.000^{*}$ & 102.7 & $.000^{*}$ & 115.9 & $.000^{*}$ & 496.9 & $.000^{*}$ & 611.5 & $.000^{*}$ \\
\hline S X C & 36.72 & $.000^{*}$ & 50.88 & $.000^{*}$ & 3.54 & .072 & 46.16 & $.000^{*}$ & 27.85 & $.000^{*}$ \\
\hline S X E & 80.30 & $.000^{*}$ & 135.3 & $.000^{*}$ & 470.5 & $.000^{*}$ & 1002 & $.000^{*}$ & 1085 & $.000^{*}$ \\
\hline Treatment & & & & & & & & & & \\
\hline E. crassipes & 10.32 & $.005^{*}$ & 6.02 & $.020^{*}$ & 1.55 & .229 & 10.41 & $.005^{*}$ & 17.44 & $.001^{*}$ \\
\hline S. auriculata & 8.17 & $.009^{*}$ & 6.77 & $.018^{*}$ & 1.18 & .292 & 8.53 & $.009^{*}$ & 12.66 & $.003^{*}$ \\
\hline
\end{tabular}

For $S$. auriculata, there are fewer data, however, for the genus Salvinia we may find concentrations of total nitrogen with values of reduction between $40 \%$ and $60 \%$ and between $35 \%$ and $50 \%$ for phosphorus, allowing for the environmental conditions under which these plants developed (Room, 1986).

In this research, E. crassipes also presented the highest percentages of nutrient reduction, when compared to $S$. auriculata. However, the percentages of nitrogen reduction (in both species) and phosphorus reduction (in S. auriculata) were quite lower than the expected in the literature. Only the percentage of phosphorus reduction presented by E. crassipes are close to those found in the literature, and may be considered high. The aquatic macrophytes received a constant amount of light $\left(170 \mu \mathrm{E} / \mathrm{m}^{2} / \mathrm{s}\right)$ throughout the incubation period.
The temperature in this experiment was not a limiting factor of the nutrient absorption rates. In addition, the nutrient concentrations themselves were not limiting and therefore, it may be inferred that the amount of light influenced the percentages of nitrogen and phosphorus reduction of the water column.

In studies with Eichhornia crassipes, UrbancBercic \& Gaberscik (1989) states that the compensation point for light intensity in this species would be between 30 and $70\left(\mu \mathrm{E} / \mathrm{m}^{2} / \mathrm{s}\right)$. Sharma $\&$ Edem (1991), reported an alteration in the growth rates in plants cultivated with low intensities of light (approximately 20, 41 and $102 \mu \mathrm{E} / \mathrm{m}^{2} / \mathrm{s}$ ), with an increase in the growth rates following the increase in light intensity. The same relationship (light X growth) was observed by Gopal (1987) in experiments with this same species, although 
with higher intensities of light (90, 320 and 750 $\mu \mathrm{E} / \mathrm{m}^{2} / \mathrm{s}$ ). This same author states that E. crassipes may survive in an ample range of light intensity and would have a saturation point around 1,500 $\mu \mathrm{E} / \mathrm{m}^{2} / \mathrm{s}$. For Roy et al. (1987), however, the saturation point would be between 1,500 and 2,000 $\mu \mathrm{E} / \mathrm{m}^{2} / \mathrm{s}$.

These results, with small fluctuations, also apply for Salvinia auriculata regarding the light influence on growth. Martins-loução et al. (1993), working with three different species of Salvinia (including $S$. auriculata) has shown through laboratory experiments that this species can absorb nitrogen in individuals cultivated with $200 \mu \mathrm{E} / \mathrm{m}^{2} /$ $\mathrm{s}$ of light and over a photoperiod of 16 hours. The values of light intensity may have been responsible for the low rates of nitrogen reduction by the individuals of $E$. crassipes and $S$. auriculata, and apparently this species was the one that suffered the most with the low levels of light incidence. The realisation of other experiments with higher levels of light incidence would be of utmost importance for the confirmation of these assertions.

The increasing photoperiod reflected a higher percentage of nutrient reduction for the two observed species. Eichhornia crassipes even under low light intensities, had high percentages of phosphorus absorption. The adequate combination of temperature and light intensity propitiates an increase in the nutrient removal capacity. Therefore, we may expect that in some periods of the year (e. g. summer), when we observe higher water temperatures $\left(30^{\circ} \mathrm{C}\right)$ and a greater photoperiod, the aquatic macrophytes would show higher growth rates and higher rates of nitrogen and phosphorus absorption. These results are important for the implementation and management of wastewater treatment systems in tropical areas using aquatic macrophytes.

Acknowledgments - The Program of Post-Graduation in Ecology of the Universidade Federal do Rio de Janeiro and PETROBRAS/ CAPES aided in the execution of this research. Also thanks to Caralee Stallman for the help in the english version.

\section{REFERENCES}

BRIX, H., 1993, Wastewater treatment in construction: system design, removal processes, and treatment performance, pp. 9-22. In: G. A. Moshiri (ed.), Constructed Wetlands for Water Quality Improvement. Lewis Publishers, 632p.
CARY, P. R. \& WEERTS, P. G. J., 1983a, Growth of Salvinia molesta as affected by water temperature and nutrition. I. Effects of nitrogen level and nitrogen compounds. Aquat. Bot., 16: 163-172.

CARY, P. R. \& WEERTS, P. G. J., 1983b, Growth of Salvinia molesta as affected by water temperature and nutrition II. Effects of phosphorus level. Aquat. Bot., 17: 61-70.

CARY, P. R. \& WEERTS, P. G. J., 1984, Growth of Salvinia molesta as affected by water temperature and nutrition. III. Nitrogen-phosphorus interactions and effect of $\mathrm{pH}$. Aquat. Bot., 19: 171-182.

DEBUSK, T. A. \& REDDY, K. R., 1987, Wastewater treatment using floating aquatic macrophytes: management strategies, pp. 643-656. In: K. R. Reddy \& W. H. Smith (ed.), Aquatic Plants for Water Treatment and Resource Recovery. Magnolia Publishing Inc., 1032p.

FURTADO, A. L. S., PETRUCIO, M. M. \& ESTEVES, F. A., 1997, C, N, P and pheopigments in the sediment of a brazilian coastal lagoon (Macaé, Rio de Janeiro). Rev. Brasil. Biol., 57(1): 127-134.

GOLTERMAN, H. L., CLYMI, R. S. \& OHMSTAD, A. M. 1978, Methods for Physical and Chemical Analysis of Fresh Water. Blackwell Scientific Publ. Oxford., 214p.

GOPAL, B., 1987, Water Hyacinth. Elsevier Aquatic Plant Studies 1, 471p.

GRASSHOFF, K., 1976, Methods of Seawater Analysis. Verlag Chemie, Weinheim, New York, 317p.

KADLEC, R. H. \& KNIGHT, R. L., 1996, Treatment Wetlands. Lewis Publishers, 893p.

MACKERETH, F. J. H., HERON, J. \& TALLING, J. F. 1978, Water Analysis: Some Revised Methods for Limnologists. (scientific publication n8 36) Freshwater Biological Association, Cumbria and Dorset, England.

MARTINS-LOUÇÃO, M. A., WOLLENWEBER, B. \& RAVEN, J. A., 1993, Response of Salvinia spp. to different nitrogen sources: the acid-base regulation approach. Oecol., 93: 524-530.

NUSCH, E. A. \& PALME, G., 1975, Biologische methoden für die praxis der gewässeruntersuchung. GWF-Wasser/ Abwasser, 116: 562-565.

REDDY, K. R. \& TUCKER, W. F., 1983, Productivity and nutrient uptake of water hyacinth, Eichhornia crassipes: I-Effect of nitrogen source. Econom. Bot., 37: 237-247.

REDDY, K. R. \& DEBUSK, W. F., 1985, Growth Characteristics of Aquatic Macrophytes Cultured in Nutrient-enriched Water: II. Azolla, Duckweed, and Salvinia. Econom. Bot., 39(20): 200-208.

REDDY, K. R. \& SMITH, W. H., 1987, Aquatic Plants for Water Treatment and Resource Recovery. Magnolia Publishing Inc., 1032p.

REDDY, K. R. \& D'ANGELO, 1997, Biogeochemical indicators to evaluate pollutant removal efficiency in constructed wetlands Wat. Sci. Tech. 35(5): 1-10.

ROOM, P. M., 1986, Equations relating growth and uptake of nitrogen by Salvinia molesta to temperature and the availability of nitrogen. Aquat. Bot., 24: 43-59. 
ROOM, P. M. \& KERR, J. D., 1983, Temperatures experienced by the floating weed Salvinia molesta Mitchell and their prediction from meteorological data. Aquat. Bot., 16: $91-103$.

ROY, J., LANDON, B., LARIGAUDERIE, A. \& BROCHIER, J., 1987, Growth and photosynthetic characteristics of water hyacinth in $\mathrm{CO}_{2}$ enriched greenhouses, pp. 433444. In: K. R. Reddy \& W. H. Smith (ed.), Aquatic Plants for Water Treatment and Resource Recovery. Magnolia Publishing Inc., 1032p.

SHARMA, B. M. \& EDEM, E. S., 1991, Ecophysiological studies on waterhyacinth in the Nigerian waters. Pol. Arch. Hidrobiol., 38(3-4): 381-395.

SHARMA, B. M. \& OSHODI, O. O., 1991, Effect of nutrients on the biomass of water hyacinth (Eichhornia crassipes (Mart.) Solms.). Pol. Arch. Hidrobiol., 38(34): 401-408.

TRIPATHI, B. D., SRIVASTAVA, J. \& MISRA, K., 1991, Nitrogen and phosphorus removal-capacity of four chosen aquatic macrophytes in tropical freshwater Ponds. Environm. Conserv., 18(2): 143-147.
URBANC-BERCIC, O. \& GABERSCIK, A., 1989, The influence of temperature and light intensity on activity of water hyacinth (Eichhornia crassipes (Mart.) Solms.). Aquat. Bot., 35: 403-408.

WETZEL, R. G., 1981, Limnología. Ediciones Omega S.A., $679 \mathrm{p}$.

WHITEMAN, J. B. \& ROOM, P. M., 1991, Temperature lethal to Salvinia molesta Mitchell. Aquat. Bot., 40: 2735 .

ZAKOVA, Z., PALAT, M., KOCKOVA, E. \& TOUFAR, J., 1994, Is it realistic to use water hyacinth for wastewater treatment and nutrient removal in Central Europe? Wat. Sci. Tech., 30(8): 303-311. 